\title{
The concept of Frame and the Framing Process
}

\author{
O. B. Novosadska
}

Chernivtsi National University, Ukraine

Corresponding author. E-mail: novosad.elena88@gmail.com

Paper received 26.01.18; Revised 30.01.18; Accepted for publication 02.02.18.

https://doi.org/10.31174/SEND-PH2018-150VI43-09

\begin{abstract}
A number of researches based on cognitive approach to the language phenomenon study is increasingly growing in linguistics. This approach enriches scientific research with new conceptual apparatus, different methods and experimental procedures. It also makes possible to give a fresh look on verbalization of the received information. One of the research methods used to analyze how verbal and mental units are connected is frame analysis. Concepts can be represented as frames, i.e., recursive attribute-value structures. The «schemata of interpretation», which are labeled «frames», enable individuals to «locate, perceive, identify, and label» occurrences or information.[4, p.45]. This constructionist conception of framing makes strong assumptions about individual cognitive processes structuredness of cognitive representations and theory guidedeness of information processing. These are the same assumptions that are shared or investigated by cognitive psychologists or other cognitively oriented researchers using similar terms. The Frame is multiaspect cognitive phenomenon connected with the process of lingual categorization, keeping and representing information. Due to a distinct structure of the frame and its linguocognitive status, the theory of frame is widely used in many spheres of linguistics, e.g. in studying the specifics of lexical units of national language usage; in the analyses of derivational processes; in grammatical structures analyses; in fiction, scientific, journalistic texts and their pragmatic description; in cognitive units; in theory of translation. Cognitive frames are usually expressed as "slot-filler representations", structures of interconnected roles together with constraints on the possible or likely fillers of those roles . Examples of such frames are (1) the partially ordered set of events, as well as the participants in such events, that one can expect in a typical visit to a restaurant, barbershop, or hospital, (2) stages and processes in the life cycle of a human being,(3) the organization of a human face, and countless others[10, p.51]. As humans we experience some of these frames by virtue of living on the earth, of our daily routines and of entities that we perceive; other frames appear because we are humans with bodies that respond to gravity and to our biological and emotional needs, and with the perceptual faculties that our bodies possess; we form other frames by being members of a particular culture, where we consciously or unconsciously respond to institutions, symbols, artifacts, and values of culture ; and, importantly, still other frames we have by virtue of being a part of the specific speech community that supports and is supported by culture. Thus, we have schematic knowledge about gravity, heat, and shadows, the difference between living and nonliving things, about colors, pain, joy and jealousy, about marriage, government and religion, and about weekends, heartburn, military titles.
\end{abstract}

Keywords: frame, slot, prototype, concept, cognitive units.

In every day of our conscious life, we are constantly busy manipulating abstract representations of the world around us. This human dexterity with mental representations, or concepts, has fascinated scholars since antiquity. Modern cognitive scientists formulate this fascination as two fundamental questions about the relations between language and thought. Since the 1970s, cognitive psychologists and theoretical linguists have taken rather different approaches in their study of frames and how they compose.

While there is an agreement that there must be a systematic relation between cognition of single individuals and meaning of linguistic expressions, there is no theory that could describe the relation systematically and formally. The aim of this paper is to describe a framework that is able to fill this gap. We will use frames as an adequate format to describe both mental representations and linguistic meaning.

This article presents an overview of the primary theoretical commitments, assumptions and worldview of frames. This will serve to provide an introduction to the major concerns and theoretical orientation of this rapidly expanding perspective.

There is a general conception of frame, together with allied conceptions like schema, idealized cognitive model, script, and even meme, narrative, etc.), especially as developed in cognitive sciences since the 1970s, that can be defined as any of the many organized sets of knowledge, beliefs, and patterns of practice that shape and allow humans to make sense of their experiences. Frames, in this sense, play an important role in how people perceive, remember, and reason about their experiences, how they form assumptions about the background and possible con- comitants of those experiences, and even how one's own life experiences can or should be enacted.

A frame may be defined as a psychological construct that furnishes one with a prevailing point of view that manipulates prominence and relevance in order to influence thinking and, if need be, subsequent judgment as well. Humans mentally project into their experiences and circumstances the interpretive frames that allow them to make sense of their surroundings in relation to themselves. They then normally shift frames only when some contradiction, conundrum, incongruity, or a change in the context of discourse calls for it. In other words, people only become aware of the frames that they regularly use when some necessity forces them to replace or integrate one frame with another. By inviting others (observers, listeners, readers, etc.) to conceptualize a certain topic from a predetermined point of view, a text - framer not only supplies an initial orienting mental scenario, but frequently s/he is also able to control his/her cognitive and emotive alignment as well as positive or negative response to that particular subject or issue.

The notion of frames was originally proposed by Marvin Minsky. Frames were seen as structures for representing stereotypic knowledge and expectations which would allow a system to impose coherence on incoming information[9, p.220]. Minsky's «frames paper» became highly influential among researchers and inspired the development of many frame-like or «higher-level» knowledge and structures and languages in the field. The term «frame» itself comes from the idea of a single frame in a film, and Minsky conceived of frames as sets of knowledge embedded in an interconnected retrieval network. Thus, when one frame is ac- 
cessed, connections to other possibly relevant frames would also be available. For example, if the frame for a house is accessed, connections to frames kitchen, bedroom, living room, etc., will also become available. If the kitchen frame is accessed, then other connections to cooking, washing dishes, refrigerators, and so forth, will become available[9, p.250].

Frames were intended to be large enough packets of knowledge to impose structure on a new situation, but small enough to be a flexible and modular part of a large database. Minsky's original conception of frames, however, rather vague and intuitive, and for this reason it is unclear how much of the subsequent concentration of research on higher level knowledge structures can be traced directly to the frame paradigm. After all, the idea that certain structures of knowledge impose coherence on human experience can be traced at least as far back as the philosopher Immanuel Kant. In linguistic literature, other «frame-like» higher level knowledge structures are known as Memory Organization Packets (MOPs), schemata, scripts and prototypes.

Marvin Minsky thinks of a frame as a network of nodes and relations. The «top levels» of frame are fixed, and represent things that are always true about the supposed situation. The lower levels have many terminals - «slots» that must be filled by specific instances or data. Each terminal can specify conditions its assignments must meet.(The assignments themselves are usually smaller «sub-frames»). Simple conditions are specified by markers that might require a terminal assignment to be a person, an object of sufficient value, or a pointer to a sub-frame of a certain type. More complex conditions can specify relations among the things assigned to several terminals.

Frames are particularly appealing as means for knowledge representation because psychological studies have shown that people tend to rely on knowledge from previous experience whenever possible, and they use this knowledge and adapt it to handle new or slightly different situations. So, instead of analyzing and building descriptions of each new situation as it occurs, people draw on a large collection of structures, which represents their previous experience with objects, people and situations, and use these past expectations to guide them in analyzing and representing new experiences. Thus, frames provide a structure or framework within which knowledge and expectations about specific events or experiences can be organized and applied to new situations.

In linguistics, frames were introduced in Fillmore's case grammar in order to represent verbs and the relational roles of their arguments[]. This early work laid the foundations for the development of frame semantics. The frame notion used in Frame Semantics can be traced most directly to case frames. In case grammar, the semantic roles of the arguments of predicates were considered crucial to the characterization of verbs and clauses. Case frames were understood as «characterizing a small abstract «scene» or «situation», so that to understand the semantic structure of the verb it was necessary to understand the properties of such schematized scenes»». In the early papers on Frame Semantics, a distinction is drawn between scene and frame, the former being a cognitive, conceptual, or experiential entity and the latter being a linguistic one. In later works, scene ceases to be used and a frame is a cognitive structur- ing device, parts of which are indexed by words associated with it and used in the service of understanding.

The notion can be exemplifed with the Commercial Transaction Frame, whose elements include a buyer, a seller, goods, and money. Among the large set of semantically related verbs linked to this frame are buy, sell, pay, spend, cost, and charge, each of which indexes or evokes different aspects of the frame. The verb buy focuses on the buyer and the goods, backgrounding the seller and the money; sell focuses on the seller and the goods, backgrounding the buyer and the money; pay focuses on the buyer, the money, and the seller, backgrounding the goods; and so on. The idea is that knowing the meaning of any one of these verbs requires knowing what takes place in a commercial transaction and knowing the meaning of any one verb means, in some sense, knowing the meaning of all of them. The knowledge and experience structured by the Commercial Transaction Frame provide the background and motivation for the categories represented by the words. The words, that is, the linguistic material, evoke the frame (in the mind of a speaker/hearer); the interpreter (of an utterance or a text in which the words occur) invokes the frame[7, p.250].

A number of important concepts figure into the Frame Semantics approach to linguistic description and analysis. One such concept is that of a prototype, understood as a fairly large slice of the surrounding culture against which the meaning of a word is defined and understood. For example, to understand the meaning of the word breakfast, it is necessary to understand the institutions and practices of the culture in which the category exists. In this case, it is necessary to understand the practice of eating three meals a day at more or less fixed times and that the meal eaten in the early part of the day after a period of sleep has a special menu; for this meal we use the word breakfast. The conditions which define the prototype need not all be present in order for native speakers to use the word appropriately. Speakers of American English may use the word breakfast for the meal eaten in each of the following situations: sleeping through the morning, eating eggs, toast, coffee, and orange juice at two in the afternoon; staying up all night, eating eggs, toast, etc. at seven in the morning; sleeping through the night, eating a peanut butter and jelly sandwich at seven in the morning. This range of usage can be captured in an account of word meaning which appeals to the notion of a prototype. The word breakfast provides a category which can be used in a variety of contexts; the contexts are determined by the word's prototypic use; the prototypic use is the one it has when the conditions of the background situation match the defining prototype [5,p.117-119].

The conception of prototype is one of the most important concepts of frame semantics. Frames should be understood as prototypical descriptions of scenes. A prototype has the advantage that it does not have to cover all possible aspects of the meaning of a phrase; in other words a prototype does not have to provide necessary and sufficient conditions for the correct use of a phrase. Fillmore illustrates the use of prototypes within frame semantics by analysis of the concept widow. The word widow is specified with respect to a background scene in which people marry as adults, they marry one person, their lives are affected by their partner's death and perhaps other properties. 
The advantage of a theory of meaning based on the prototype concept compared to a theory which insists on stating necessary and sufficient conditions for the meaning of a phrase is that it does not have to care about certain boundary conditions; that is it does not have to provide answers for questions like «Would you call a woman a widow who has lost two of her three husbands but who had one living one left?» Fillmore [6, p.112]. In a case like this whether the noun widow applies or not is unclear since certain properties of the background frame for this concept are missing.

Fillmore's point is that any given lexical concept is relativised with respect to and thus can't be understood without the other lexical concepts which collectively comprise the knowledge structure, or semantic frame that it forms part of. In related fashion, Langacker argues that part of the meaning of any lexical item is a function of the knowledge structure or base that is presupposed by it.[10, p,47] For instance,the lexical concept [HUMAN MAJOR ARM JOINT] associated with the form elbow cannot be properly understood without knowledge of the arm which is necessary for understanding the nature and function of the elbow.

However, as with both Fillmore's notion of a semantic frame and Langacker's notion of a base, a cognitive model is accessed, at various points by distinct lexical concepts, which are thus relativised to it, and in part, collectively constitute it. In other words, a cognitive model represents an interface between

richly-specified conceptual knowledge and nodes of access at particular points in the cognitive model provided by specific lexical concepts. Thus, lexical concepts provide particular perspectives or construals with respect to the cognitive model, in part, constituting it. Yet, a cognitive model is far richer than the sum of the lexical concepts which provide access sites to it. This follows as while lexical concepts are

conceptual units specialised for symbolic representation in language, cognitive models are not. Rather, they are multi-model conceptual entities, which can be used as a basis for what Barsalou and others refer to as simulations.

According to Barsalou, frames, understood as recursive attribute-value structures, are used as general format in accounting for the content of mental concepts. Advancing the basic ideas of Minsky, Barsalou argues for frames as "dynamic relational structures whose form is flexible and context dependent". [1, p.60]He presents psychological evidence for attribute-value structures derived from behavioral animal studies. These studies indicate that animals encode stimulus information as attribute values and not as independent features. Furthermore, he gives empirical evidence for the importance of conceptual relations in human cognition. The attributes in a concept frame are the general properties or dimensions by which the respective concept is described (e.g. COLOUR, SPOKESPERSON, HABITAT...). Their values are concrete or underspecified specifications (e.g.,[COLOUR:red], [SPOKESPERSON: Mary Hollaway],[LOCATION:Beach]..) For example, ball can be characterized by [SHAPE:round], specifying its concrete shape, and [COLOR:color],specifying that it has a color which is not further specified. For example, color describes an aspect of birds, and location describes an aspect of vacations. A concept is only an attribute when it describes an aspect of a larger whole. When people consider color in isolation (e.g., thinking about their favourite color), it is not an attribute but is simply a concept. Similarly, when people think about location in isolation (e.g., in geography), it is not an attribute. A concept is only an attribute when viewed as describing some aspect of a category's members. Color becomes an attribute when viewed as an aspect of bird, and location becomes an attribute when viewed as an aspect of vacation[ 3,p.570].

Due to their recursivity, frames are flexible enough to represent information of any desired grade of detail. We assume that attributes in frames assign unique values to objects and thus describe functional relations. Formally, frames can be represented by connected directed graphs where the arcs correspond to attributes. As attributes are functions, no node may have two equally labeled outgoing arcs. The nodes may be labeled by types which restrict the attribute domains and ranges, i.e. the set of objects for which an attribute is adequate and the set of values an attribute can take.

Frames are rich enough to provide a detailed and adequate description of individual's mental representation, in particular the representations of concepts. Due to their recursive structure, they are apt to describe concepts at different levels of granularity.

\section{REFERENCES}

1) Barsalou, Lawrence. Cognitive Psychology: An Overview for Cognitive Scientists // Hillsdale, NJ: Lawrence Erlbaum,1992.P.56-89

2) Barsalou, Lawrence. Frames, concepts and conceptual fields// In A. Lehrer and E. Kittay (eds.). Frames, Fields and Contrast. Hillsdale, NJ: Lawrence Erlbaum. P.21-74

3) Barsalou, Lawrence. Perceptual symbol systems //Behavioral and Brain Sciences, 22, 1999. P. 577-609.

4) Evans, Vyvyan and Melanie Green.. Cognitive Linguistics: An Introduction //Edinburgh: Edinburgh University Press,2006. p. 830

5) Fillmore, Charles. Frame semantics // The Linguistic Society of Korea (ed.), Linguistics in the Morning Calm, 1982 . P. 111137.

6) Fillmore C. J. Frame Semantics and the Nature of Language // Origins and Evolution of Language and Speech / eds. S. R. Harnad, et al. N. Y.: New York Academy of Sciences, 1976. P. 20-32.

7) Fillmore, Charles. Frames and the semantics of understanding'//Quaderni di Semantica, 6, 1985. PP. 222-254.

8) Fillmore, Charles, and Beryl T. Atkins. Toward a frame-based lexicon: The semantics of RISK and its neighbors// In A. Lehrer and E. F. Kittay (eds.), Frames, Fields and Contrasts. Hillsdale, NJ: Lawrence Erlbaum,1992. P.77-80

9) Minsky M. A Framework for Representing Knowledge // The Psychology of Computer Vision / ed. P. H. Winston. N. Y.: McGraw Hill, 1975. P. 211-277.

10) Langacker, Ronald. Foundations of Cognitive Grammar// Volume I. Stanford: Stanford University Press,1987. P.45-65

11) Petruch M. Frame Semantics // Handbook of Pragmatics / eds. J. Verschueren, J.-O. Ostman, J. Blommaert and C. Bulcaen. Amsterdam: Benjamins, 1996. P. 1-13.

12) Tannen, Deborah. What's in a frame? Surface evidence for underlying expectations// In New Directions in Discourse Processing, ed. by Roy Freedle. Norwood: Ablex,1979. P.137-181. 


\section{Категория и структура фрейма}

О. Б. Новосадская

Аннотация. За последние несколько дней увеличилось количество исследований в языкознание, в основе которых лежит когнитивный подход к изучению языковых средств. Такой поход обогатил лингвистические исследования новым концептуальным аппаратом, разными методами и экспериментальными процедурами, дал возможность по новому подойти к решению проблем вербализации информации. В настоящее время многими учёными признаётся тот факт, что наиболее эффективным приемом изучения структуры знаний и принципов их организации в языковой системе является понятие фрейма. Использование фрейма как метода исследования связано с постулированием определенной зависимости языкового значения от познавательного опыта человека. Соответственно - это метод исследования взаимодействия семантического пространства языка и структур знания мыслительного пространства, то есть метод когнитивно-семантического моделирования языка. Фреймовая модель представления знаний образовалась на основе теории фреймов М. Минского и представляет когнитивную модель памяти человека. В ее основе - положение о восприятии человеком действительности через сопоставление имеющихся в памяти фреймов, каждый из которых связан с конкретным концептуальным объектом памяти и информацией, получаемой из мира действительности. Фрейм как структура данных имеет слоты и терминалы, которые являются когнитивными компонентами, входящими в наши представления о явлениях, событиях и предметах окружающего мира. Слоты - своеобразные ячейки, которые могут быть заполнены различными в каждом конкретном случае группами слов, представляющими потенциальные возможности языковой актуализации фрейма. Фреймы оказались экономным способом передачи информации, ускоряющим процесс ее обработки, так как они наряду с явными содержат и скрытые, подразумеваемые сведения. Поскольку теория фреймов имела целью объяснение высокой скорости человеческого восприятия и мышления, она не могла не заинтересовать философов и лингвистов. После того как термин фрейм стали применяться в лингвистике, он, наряду с первоначальным (структурным) значением, получил множество дополнительных толкований. Фрейм - многоаспектный когнитивный феномен, связан с процессом языковой категоризации, сохранением и представлением информации. Чёткая структура фрейма, его лингвокогнитивный статус обусловили широкое использование теории фреймов в разных направлениях лингвистических исследований, в частности: в анализе грамматических структур национального языка; в исследованиях когнитивных единиц и процессов; в анализе языковых актов; в описание структуры художественного, научного и публицистических текстов. Использование структуры фрейма облегчает задачу анализа языкового материала, дает возможность систематизировать и подробнее рассмотреть отдельные единицы, составляющие тот или иной слот, входящий в структуру данной модели. Фреймы непосредственно участвуют в процессе речевого общения, привлекая содержащиеся в них экстралингвистические знания о мире. Представление знаний о мире с помощью систем фреймов оказывается весьма плодотворным во многих областях исследований по искусственному интеллекту, начиная от понимания естественного языка и кончая проблемами машинного восприятия слуховых и зрительных образов.

Ключевые слова: фрейм, структура фрейма слот, прототип, концепт. 